\title{
Preceding Dividend as a signal of Future Dividends: Evidence from Chinese Commercial Banks
}

\author{
Akhtiar Ali ${ }^{1}$, S. Karim Bux ${ }^{2}$ and Naveed R Khan ${ }^{3}$
}

\begin{abstract}
:
Dividend policy is a prime concern of all stakeholders for it represents major cash outflow. Understanding the causes that affect dividend policy is of a prime concern for investors and academia. Firm specific and market specific factors are chosen from extant literature for empirical analysis. Secondary data is used for statistical analysis the empirical results indicate significant relationship of provisioning against nonperforming loans (LNPNPL), total assets (LNTA) and return on assets (ROA) on dividend payout ratio. LNPNPL significantly and negatively causes dividend policy, this indicates that banks with higher level of risk pay less dividends. Similarly, ROA significantly and positively explains variations in dividend payout ratio. The positive relationship tells that banks with higher returns (profitable banks) pay higher dividends. The negative and significant relation (causal) between LNTA and dividend payout indicates that Chines banks pay less dividends as they grow bigger in size. Other variables of model indicate insignificant relationships. Findings support existing literature but the size of bank has significant but inverse relationship with dividend policy. The findings open space for further work since size of the bank shows negative relationship with dividend payout ratio.
\end{abstract}

Keywords: Banking Industry, Emerging Markets, Dividend policy, India, China, Pakistan.

JEL Classification: G14, G3, G23, G21

\section{Introduction}

Dividend policy is characterized by making a right decision of distributing earned money in a way that all shareholders of firm are satisfied. The prime objective does not

${ }^{1}$ Associate Professor, Management Sciences, Bahria University Karachi Campus

${ }^{2}$ Assistant Professor, University of Sindh, Jamshoro.

${ }^{3}$ Associate Professor, Management Sciences, Bahria University Karachi Campus

Corresponding Email: naveed.r.khan@gmail.com 
limit at satisfying the stakeholders needs, managers need to consider the growth factor for future prospects. In addition, it is important to consider the possible implication of dividend policy on various firm specific and market specific elements. It is noteworthy for managers to consider the possible effect of their dividend decision on share prices (Bishop et al. 2000). Dividend policy is a critical decision since it influences other real or financial investment decisions (Abor \& Bokpin, 2010).

Researchers have employed different factors to understand dividend policy such as operating and demographic characteristics of firm and CEOs to explain dividend policy (see for example Huang, JJ., Shen, Y \& Sun, Q., (2011); Grullon et al., 202); structure of shareholding (see for example Abdelsalam (2008); Ramli (2010); Hafeez (2009); earnings Watts (1973), Nissim (2001) and also work on irrelevance of dividend policy by M\&M (1961).

Numerous studies tried to explain dividend policy using various factors but the issue remains unresolved. Dividend policy is among top ten unsolved issues in field of economics and finance as various studies could not provide e (consistent) explanation for dividend behavior of firms (Black, 1976). Hence the study of dividend policy has relevance and significance for further understanding. A close look at existing literature reveals an interesting fact that a big chunk of pie on dividend policy studies is based on non-financial sector. There are a few and country-limited studies that discussed the dividend policy in financial sector. Furthermore, most of studies are done using data of developed nations. There is great need to carry study for better understanding of subject in financial market of emerging economies. Keeping in view this need, the present study tried to explore the dividend determinants of commercial banks in emerging markets. The present model includes firm-specific, market-specific and country-specific factors. The present model is based on three key studies, Fama and French (2001), Lintner (1956) and Casey, K. Michael, and Ross N. Dickens, (2000). We have carefully designed present model after removing key reservation on referred models. The provisioning against non-performing loans, growth in GDP and ownership status are new variables, similarly, ownership status (private / government dummy) is a dummy variable that differentiates government and private banks in sample set. The ownership status dummy variable helps to understand if government and private banks consider different factor(s) while making dividend decisions. The inclusion of regulatory variable (PETTAR, equity to total assets ratio) and market capitalization to GDP ratio for equity market developments as a new variable would enhance the understanding of dividend policy as this makes model more novel, comprehensive and significant.

\section{Hypothesis setting based on literature review}

Assets show the important section of financial health of bank. This study uses total assets as proxy for size as suggested by Fama and French (2001). Size of firm has significant and positive relationship with dividend payout Mark (1998). Two additional factors may motivate firms to pay higher dividends. First, transaction cost for raising funds, which is relatively lower for bigger firms compared to smaller and second investors perceive large firms less risky. Hence, big firms (in terms of size) tend to pay

Sukkur IBA Journal of Management and Business - SIJMB | Vol 7 No. 2 July - December 2020 @ Sukkur IBA University 
higher dividends because they can easily raise funds if required (see for example, Alli, 1993; Adedeji, 1998; Eriotis, 2005; Ramli, 2010; and Al-Malkawi, 2007) tried to study relationship between dividend payout ratio and size of firm and found a positive and significant relationship. The study suggested that large firms have excessive cash flow (internally generated) so they tend to pay regular and higher dividends. Afza \& Mirza (2010) found consistent findings for non-financial sector. They concluded that large size firms possess quality assets, hence; it is easy for them to collect funds from external sources to fund potential projects. However, there are studies that disclosed negative relationship between size of firm and dividends (see for example, Hafeez \& Attiya, 2009; and Ahmed, HJA \& Shaikh, JM., (2008).). They suggested that large size firms tend to rely on internally generated funds; hence, they hold funds under their control for further growth. Zulfiqar \& Hui (2010) Compared dividend policy of listed Chinese and Pakistanis firms and concluded that in Pakistan large size firms tend to pay dividends whereas in china, small size firms tend to pay higher dividends.

The extant literature provided mixed findings on relationship between dividends and size of firm. Some of them came up with positive and significant relationship, whereas, others concluded negative or insignificant relation. Hence, we reiterate the model and set first hypothesis as under:

\section{H1a: Size of bank has positive and significant impact on dividend payout ratio.}

Firms pay dividends from profits. We have used return on assets (ROA) as a proxy for profitability. Amidu \& Abor (2006) took six years data of listed firms in Ghana and found a positive and significant relationship between profitability and dividend payout ratio. Pruitt \& Gitman (1991) used survey approach to assess relation between profit and dividend payout ratio in U.S and concluded that both current and past profits significantly cause current dividend payout ratio. Numerous studies suggest a positive and significant relationship between profitability (both ROA and EPS were used as proxy for profitability) and dividend payout ratio (see for example: Naeem \& Nasr, 2007; Truong \& Heaney, 2007; Rodríguez-Pose \& Gill, 2005; Al-Malkawi, 2007; and Matthias \& Akpomi, 2008). However, a few studies found an inverse correlation between profitability and dividend payout ratio. Okpara \& Chigozie (2010) concluded firms tend to reduce dividends despite of earnings to plough back earning for growth. Similarly, Barclay (1995) found negative correlations between profitability and dividend payout ratio. Adedeji (1998) concluded that profitability is irrelevant in explaining dividend payout ratio.

Various studies have explored relationship between profitability and dividend payout ratio but findings are quite mixed. Therefore, present study used (ROA) as proxy for profitability to test its relation with dividend payout ratio of commercial banks in emerging market.

Sukkur IBA Journal of Management and Business - SIJMB | Vol 7 No. 2 July - December 2020 @ Sukkur IBA University 
H2a: Profitability significantly and positively influences dividend payout ratio.

In continuation of argument related to Fama and French model present study used changes in total assets as proxy for growth. Firms at growth stage faced with investment opportunities tend to retain more to fund potential projects, hence, they pay either little or no dividends (Al-Malkawi, 2007; and Gaver \& Gaver, 1993). Authors have suggested a negative and significant correlation between growth and dividend payout ratio and lend support to pecking order hypothesis. Grullon et al., (2002) found that young and startup firms tend to hold reserves to finance potential growth and pay either low or no dividends. On the contrary, mature firms tend to pay since they do not have enough growth opportunities. D'Souza (1999) concluded that there is trade-off between investment opportunities and dividend payments. Hence, at time of rise of investment opportunities dividend payments tend to fall and in absence of growth opportunities firms pay higher dividends to minimize agency cost. Shin et al., (2010), found significant and opposite correlation between dividends and growth. The study concluded that mature firms have surplus cash flow and usually do not find potential growth prospects, so, they tend to increase dividend payments. Mitton (2004) suggested a strong negative correlation between growth opportunities and dividend payouts with specific reference to countries where shareholders' rights are protected. There are numerous studies in both emerging and developed economies that support the argument that firms at growing stage tend to lower dividends because they rely on internally generated profits to fund the potential investment opportunities (see for example: (Patra et al., 2012; Kangarlouei et al., 2012; Abor \& Bokpin, 2010; Amidu \& Abor, 2006). Although, growth plays significant role in explaining dividend policy, but, there are few studies that concluded not significant and positive relation between them. Arnott \& Asness (2003) used data of America stock market and concluded that firms at growing stage tend to pay higher dividends. With respect to Pakistan context, Hafeez \& Attiya (2009) used data of listed firms of Karachi stock exchange and found no significant correlation between growth and dividend payout. The review of existing literature provides mixed evidence on relation between growth of firm and dividend payout. Therefore, we have used this hypothesis in our study to test how it works for commercial banks in emerging markets

H3a: Growth oriented firms tend to lower dividend payout. Therefore, we expect a negative relation between growth and dividends.

Non-performing loan (NPL) is a loan (part or whole) that default at payback payments (interest / principal) or close to default. As a general practice, banks create provisioning of certain amount on loans that are past due by 90 days. NPL is an income statement item and it is deducted from mark-up /interest earned/ return account. This has direct impact on net income of bank. Higher NPL means bank is less profitable. Although, there are means to recover non-performing loans but that costs extra effort and cost. Higher NPL makes earnings volatile and makes lending riskier. Risk may have different

Sukkur IBA Journal of Management and Business - SIJMB | Vol 7 No. 2 July - December 2020 @ Sukkur IBA University 
forms based on perspective that you want to analyze. Investors may treat a firm as risky based on unstable earnings or divided policy. Management may find risk in pursuing new project or risk in shape of costly source of financing. For financial industry, the risk of non-performing loans is of key interest. Interest income on lending is key source of earning of banks; but not all lending decisions perform well. Banks deduct a certain amount as a provision for non-performing loans. Higher amount of provisioning lowers the earnings. Hence provisioning on advances is taken as a proxy for risk. Based on this rationale, the study postulates a negative relationship between dividends and amount of provisioning for non-performing loans.

\section{H4a: NPL hampers the earnings of firms hence firms with higher NPL tend to pay less dividends.}

Firms tend to stabilize dividend payments around a set target thus; they choose to distribute a certain amount of profit each year. So dividend paid in preceding year serves as a signal of future dividend payment(s). In other way, cut or omission of dividends indicates the chances of volatility of earnings. Lintner (1956) survey based analysis of link between dividends and value of firm conclude that managers are unwilling to reduce or omit dividends since they think it reduces price of share in market. Therefore, cut or omission of dividends would have negative impact on value of firm. This is one of the early studies to provide basis for signaling hypothesis. The study invited attention of researchers. Many academicians tried to study the implication and relevance of signaling hypothesis in different markets and industries but results are mixed. Rehman (2012) found a positive and significant relationship between last year dividend and current period dividends. The study suggested that firms avoid cutting or omitting dividend payments but tend to increase it gradually. Pandey \& Bhat (2007) reached findings consistent with Lintner (1965) and stated that firms in India tend to set a targetdividend payout ratio. However, they face high level of difficulty to adjust it around already set payout ratio in case of volatile earnings. Okpara \& Chigozie (2010) tested relationship between dividend paid preceding year with current dividend payout, using data of Nigerian firms, and found positive and significant relationship. However, Sheikh (2011) used Greek bank industry and concluded that firms neither set target dividend payout ratio nor follow long-term dividend payout pattern. Hence, there is no significance relation between preceding to current dividend payments. Firms pay dividends from profits generated after setting off certain cushion for potential projects; hence, last dividends do not significantly cause current dividends. The findings have shown mixed results, so, this study tends to test the relationship as under:

H5a: Banks follow stable dividend policy hence last dividends have positive impact on current dividends.

The structure of shareholding may be viewed in different ways, such as, concentration of majority shareholders, percentage of foreign shareholders, percentage of insiders (ie directors, Executives, or their spouses) and individual investors. Abdelsalam (2008)

Sukkur IBA Journal of Management and Business - SIJMB | Vol 7 No. 2 July - December 2020 @ Sukkur IBA University 
Concluded that firms with high percentage of institutional ownership combined with high rate of return on equity tend to pay regular and higher dividends. The plausible explanation is that institutions do not tend to invest in a specific firm for long term. Therefore, the presence of higher institutional ownership is signal that firm will pay higher dividends. Ramli (2010) concluded a positive association between concentration of majority shareholders and dividend payout. The study on non-financial firms listed in Karachi stock exchange Pakistan shows direct association between dividends and insider ownership Hafeez (2009). One possible reason is that the distribution of higher dividends shall benefit the directors and other insiders of firm for they better know the financial health of firm. Most of fund management firms tend to rely on regular dividends, such as, pension funds, but other financial institutions rely more on capital gain since they do not tend to speculate in stock market and they face double taxation. Therefore, they prefer capital gains to dividends. The findings present evidence for both kinds of relationships. So, we postulate following hypothesis:

\section{H6a: The concentration of institutional ownership positively influences dividend payments.}

The overall market growth brings many possibilities for all firms. The overall market position may have effect on firms in many ways including on their dividend policy. Market movement is taken as a ratio of market capitalization to GDP, used as proxy to measure growth of financial asset (equity) market. Market capitalization is total market value of shares (outstanding) of listed firms. High value of market capitalization to GDP shows higher degree of development of financial asset market and higher degree of (investment) confidence of investors. It is obvious that the confidence of investors depend on the rate of return from their investments in financial asset market. Therefore, the present study sets proposition as under to check the impact of market growth on dividend policy.

H7a: Banks tend to pay higher dividends as market capitalization to GDP ratio of listed firms increase.

GDP is a key economic indicator that is used as yardstick to measure economic performance of specific country. The growth in GDP indicates the overall economic developments of specific economy. The general growth in GDP indicates the overall positive performance of an economy. Therefore, this is indication that all economic units are performing in upward direction. Similarly, the equity market prospers at times of growing GDP. This will reflect in performance of all industries including commercial banks. Based on this argument, we hypothesize following statement:

\section{H8a: Banks tend to pay higher dividends with positive change in GDP.}

Firms do not operate in isolation for they work under strict regulation. The regulatory authorities set certain mandatory requirements for all listed firms. The requirements

Sukkur IBA Journal of Management and Business - SIJMB | Vol 7 No. 2 July - December 2020 @ Sukkur IBA University 
may vary in scope however, it has impact on firms in many ways. Therefore, firms in tight regulatory setting behave in different way. It is common that regulatory bodies (mostly central/state banks) impose certain conditions on banks related to maintenance of equity level. Equity to total assets ratio (PETTAR) is taken as a proxy to measure to calculate regulatory pressure. As stated higher ratio of PETTAR indicates low possibility of distribution of earnings for shareholders. Therefore, we expected a negative causal relationship between PETTAR and dividend payout ratio. We hypothesize the statement as under:

\section{H9a: Banks at times of higher regulatory pressure to maintain certain equity level tends to distribute less dividends.}

Public and private banks work in same industry however, their working environments differ a lot. The change in work environments have different impact on banks and their changes sometimes impact their financial and non-financial decisions. The study uses dummy variable (PGDUMMY) to measure ownership of bank and it takes value of "1" if banks is state-owned entity and " 0 " if bank is private owned entity. PGDUMMY would control for variations in dependent variable if the state-owned and non-state owned (private) banks behave differently. The state-owned banks enjoy many advantages over private banks. Hence, we postulate a positive causal relationship between state-owned banks and dividend payout ratio.

\section{H10a: State-owned banks tend to pay higher dividends.}

The present study uses a model that is an extension of three different models; that firms set target dividend payout ratio and adjust current dividends by considering the target payout ratio Lintner (1956); that size, growth and profitability are key factors that influence dividend policy size Fama and French (2001) and Dickens et al. (2002) bank level regulatory pressure to see its impact on dividend policy. Following is the mathematical representation of hypothesis based on extant literature.

$$
\begin{gathered}
\text { DIV }_{\text {it }}=\alpha+\beta_{1 \mathrm{t}} \mathrm{LNTA}_{\mathrm{it}}+\beta 2 \mathrm{tROAit}+\beta 3 \mathrm{tGRAit}+\beta 4 \mathrm{tLNPNPLit}+\beta 5 \mathrm{tLNDPLY}_{\text {it }} \\
+\beta 6 \mathrm{t} \mathrm{SHBII}_{\mathrm{it}}+\beta_{7 \mathrm{t}} \text { MCGDP }_{\mathrm{it}}+\beta_{8 \mathrm{t}} \text { PETTAR }_{\mathrm{it}}+\varepsilon \mathrm{it}
\end{gathered}
$$

Where,

DIV $_{\text {it: }}$ represents dividend payout ratio of ith bank in year $t$. The variable is in percent form and used as a dependent variable in model.

LNTAit : represents total asset of ith bank in year t. This variable represents size of bank (used as a proxy). Total assets are presented in model in natural log.

ROAit : represents return on assets of ith bank in year $t$. The variable in in percent form and used as a proxy for profitability of firm.

GRAit : represents change in assets of ith bank in year $t$. The variable in in percent form and used as a proxy for growth of firm.

LNPNPLit : represents provisioning for non-performing loans of ith bank in year t.

Sukkur IBA Journal of Management and Business - SIJMB | Vol 7 No. 2 July - December 2020 @ Sukkur IBA University 
This variable represents risk level of bank and transformed into natural log.

LNDPLYit : represents dividend paid by ith bank in year $\mathrm{t}$. The variable is transformed into natural log.

SHBIIit : represents percent of shares held by institutional investors of ith bank in year t. The variables represent the negotiation power of institutional investors.

MCGDPit : represents market capitalization to GDP ratio of listed firm of ith stock market (stock exchange) in year $\mathrm{t}$. The variable in in percent form and used as a proxy to measure the development of equity market in specific country.

GGDPit : represents growth in gross domestic product of ith country in year t. The variable measures the overall growth in given country.

PETTARit : represents equity to total assets ratio. This variable is in percent form and taken as proxy for regulatory pressure in given market.

\section{Descriptive Statistics (China)}

There are 15 banks operating in China that make up the final sample. Annual data for 10 years on each bank is collected. Hence, there are 150 number of observations.

Table 1: Descriptive Statistics for study variables

\begin{tabular}{|l|l|l|l|l|}
\hline Variable & Mean & Maximum & Minimum & Std. Dev. \\
\hline LNTA & 18.417 & 20.470 & 15.460 & 1.115 \\
\hline ROA & 1.022 & 1.734 & 0.129 & 0.294 \\
\hline GRA & 26.258 & 81.220 & 3.520 & 12.785 \\
\hline LNPNPL & 13.877 & 18.340 & 10.110 & 1.448 \\
\hline PDPR & 25.403 & 45.780 & 6.000 & 7.633 \\
\hline LNDPLY & 12.961 & 16.530 & 9.310 & 1.903 \\
\hline SHBII & 38.385 & 97.480 & 1.190 & 26.498 \\
\hline PETTAR & 5.516 & 13.714 & 1.057 & 2.165 \\
\hline MCGDP & 0.728 & 1.782 & 0.346 & 0.410 \\
\hline
\end{tabular}

Descriptive statistics table 1 shows central tendency and dispersion along with minimum and maximum values in data set of variables of model. The average total assets is 18.417 with standard deviation of 1.115 . The maximum and minimum total assets during the study period were 20.470 and 15.460 respectively. The study uses return on assets as a substitute for profitability. Chinese banks, during study period, earned on average return of 1.022 percent compared to total assets. The average growth in total assets was 26.25 percent with standard deviation of 12.785 . The provisioning against non-performing loans (PNPL) is substitute to measure the volatility in earnings. Higher value of PNPL represents shrinks the profit that may cause instability in earnings. The average PNPL for sample banks during study period was 13.877 with standard deviation of 1.448 units. At least one observation on PNPL had minimum and maximum value as 10.11 and 18.340 respectively. The description for all other variables

Sukkur IBA Journal of Management and Business - SIJMB | Vol 7 No. 2 July - December 2020 @ Sukkur IBA University 
is similar as discussed for few variables.

Table 2: Correlation matrix (China)

\begin{tabular}{|c|c|c|c|c|c|c|c|c|c|c|}
\hline & & $\begin{array}{l}\text { LNT } \\
\text { A }\end{array}$ & $\begin{array}{l}\text { RO } \\
\text { A }\end{array}$ & $\begin{array}{l}\text { GR } \\
\text { A }\end{array}$ & $\begin{array}{l}\text { LNP } \\
\text { NPL }\end{array}$ & PDPR & $\begin{array}{l}\text { LND } \\
\text { PLY }\end{array}$ & SHBII & $\begin{array}{l}\text { PET } \\
\text { TAR }\end{array}$ & $\begin{array}{l}\text { MCG } \\
\text { DP }\end{array}$ \\
\hline \multirow{2}{*}{ LNTA } & $\begin{array}{l}\text { Pearson } \\
\text { Correlation }\end{array}$ & 1 & & & & & & & & \\
\hline & $\begin{array}{ll}\text { Sig. } \\
\text { tailed) }\end{array}$ & & & & & & & & & \\
\hline \multirow{2}{*}{ ROA } & $\begin{array}{l}\text { Pearson } \\
\text { Correlation }\end{array}$ & .115 & 1 & & & & & & & \\
\hline & $\begin{array}{ll}\begin{array}{l}\text { Sig. } \\
\text { tailed) }\end{array} & (2- \\
\end{array}$ & .159 & & & & & & & & \\
\hline \multirow[t]{2}{*}{ GRA } & $\begin{array}{l}\text { Pearson } \\
\text { Correlation }\end{array}$ & -.109 & $\begin{array}{l}.20 \\
0^{*} \\
\end{array}$ & 1 & & & & & & \\
\hline & $\begin{array}{ll}\begin{array}{l}\text { Sig. } \\
\text { tailed) }\end{array} & (2- \\
\end{array}$ & .183 & $\begin{array}{l}.01 \\
4 \\
\end{array}$ & & & & & & & \\
\hline \multirow{2}{*}{$\begin{array}{l}\text { LNPN } \\
\text { PL }\end{array}$} & $\begin{array}{l}\text { Pearson } \\
\text { Correlation }\end{array}$ & $.165^{\star}$ & $\begin{array}{l}.18 \\
0^{*}\end{array}$ & $\begin{array}{l}.47 \\
6^{* *} \\
\end{array}$ & 1 & & & & & \\
\hline & $\begin{array}{ll}\begin{array}{l}\text { Sig. } \\
\text { tailed) }\end{array} & (2- \\
\end{array}$ & .044 & $\begin{array}{l}.02 \\
7 \\
\end{array}$ & $\begin{array}{l}.00 \\
0\end{array}$ & & & & & & \\
\hline \multirow[t]{2}{*}{ PDPR } & $\begin{array}{l}\text { Pearson } \\
\text { Correlation }\end{array}$ & -.032 & $\begin{array}{l}.56 \\
9^{* *}\end{array}$ & $\begin{array}{l}.06 \\
6\end{array}$ & .034 & 1 & & & & \\
\hline & $\begin{array}{ll}\begin{array}{l}\text { Sig. } \\
\text { tailed) }\end{array} & (2- \\
\end{array}$ & .696 & $\begin{array}{l}.00 \\
0 \\
\end{array}$ & $\begin{array}{l}.42 \\
4 \\
\end{array}$ & .680 & & & & & \\
\hline \multirow{2}{*}{$\begin{array}{l}\text { LNDP } \\
\text { LY }\end{array}$} & $\begin{array}{l}\text { Pearson } \\
\text { Correlation }\end{array}$ & $.260^{*}$ & $\begin{array}{l}.49 \\
4^{* *}\end{array}$ & $\begin{array}{l}.48 \\
5^{* *}\end{array}$ & .716 & $.301^{* *}$ & 1 & & & \\
\hline & $\begin{array}{ll}\begin{array}{l}\text { Sig. } \\
\text { tailed) }\end{array} & (2- \\
\end{array}$ & .001 & $\begin{array}{l}.00 \\
0 \\
\end{array}$ & $\begin{array}{l}.00 \\
0 \\
\end{array}$ & .000 & .000 & & & & \\
\hline \multirow{2}{*}{ SHBII } & $\begin{array}{l}\text { Pearson } \\
\text { Correlation }\end{array}$ & $.316^{*}$ & .44 & $\begin{array}{l}- \\
.24 \\
2^{* *}\end{array}$ & .293 & .142 & .454 & 1 & & \\
\hline & $\begin{array}{ll}\text { Sig. } & (2- \\
\text { tailed) } & \\
\end{array}$ & .000 & $\begin{array}{l}.00 \\
0\end{array}$ & $\begin{array}{l}.00 \\
3\end{array}$ & .000 & .082 & .000 & & & \\
\hline \multirow{2}{*}{$\begin{array}{l}\text { PETT } \\
\text { AR }\end{array}$} & $\begin{array}{l}\text { Pearson } \\
\text { Correlation }\end{array}$ & $-162^{*}$ & $\begin{array}{l}.55 \\
3^{* *} \\
\end{array}$ & $\begin{array}{l}.03 \\
6 \\
\end{array}$ & .118 & $.250^{* *}$ & .173 & $.214^{* *}$ & 1 & .054 \\
\hline & $\begin{array}{ll}\text { Sig. } \\
\text { tailed) }\end{array}$ & .047 & $\begin{array}{l}.00 \\
0\end{array}$ & $\begin{array}{l}.66 \\
2\end{array}$ & .151 & .002 & .034 & .008 & & .515 \\
\hline \multirow{2}{*}{$\begin{array}{l}\text { MCG } \\
\text { DP }\end{array}$} & $\begin{array}{l}\text { Pearson } \\
\text { Correlation }\end{array}$ & $-243^{*}$ & $\begin{array}{l}- \\
.27 \\
3^{* *}\end{array}$ & .34 & -101 & -.090 & .265 & $-.306^{* *}$ & .054 & 1 \\
\hline & $\begin{array}{ll}\begin{array}{l}\text { Sig. } \\
\text { tailed) }\end{array} & (2- \\
\end{array}$ & .003 & $\begin{array}{l}.00 \\
1 \\
\end{array}$ & $\begin{array}{l}.00 \\
0 \\
\end{array}$ & .217 & .273 & .001 & .000 & .515 & \\
\hline
\end{tabular}

*. Correlation is significant at the 0.05 level (2-tailed).

**. Correlation is significant at the 0.01 level (2-tailed). 


\section{Correlation Analysis (China)}

Total assets (proxy for size of bank) has significant correlation with all study variables except return on assets (ROA), growth in assets (GRA) and dividend payout ratio (PDPR). Among statistically significant relationships, it has positive and weak relationship with dividend paid last year (DPLY), provisioning against non-performing loans (PNPL) and shareholding by institutional investors (SHBII) and has weak and negative relationship with rest of variables. Percent change in total assets (GRA, proxy for growth in assets) has significant correlation with LNPNPL, LNDPLY SHBII and MCGDP. Among significant relationships, it has negative association with all variables except MCTGDP. The rest of relationships has similar interpretation.

\section{Results of Regression Analysis (China)}

The study uses panel data. Hausman test ( $\mathrm{p}$ value $<0.05)$ hence, we have used fixed effect (LSDV) model to run regression.

Coefficient values indicate each variable's effect on dependent variable if all other factors are kept constant. P-value represents the significance of causal relationship. Rsquared value represents the overall explanatory power of model. F-statistics indicates the overall fitness of model to given data. Durbin-Watson statistics measures the presence of serial autocorrelation.

Refer Table 1-3; the model explains approximately 45.3 percent $(\mathrm{R}$-squared $=0.453)$ variations in dividend payout ratio. F-statistics tests the condition that in a certain given model all of the parameters (coefficients values) are jointly zero. The P-value for Fstatistics is significant $p$ value $<0.005(0.000000)$. This means that all coefficient values of all significant variables are different from zero. Furthermore, size of firm (LNTA), profitability (ROA) and provisioning against non-performing loans (LNPNPL) are significant determinants of dividend policy. LNTA and ROA are significant at 1 percent and LNPLPL is significant at $10 \%$ of significance level.

Table 3: Regression Results

\begin{tabular}{|l|l|l|l|l|}
\hline Variable & Coefficient & Std. Error & t-Statistic & Prob. \\
\hline C & 51.40979 & 11.97014 & 4.294837 & 0.00000 \\
\hline LNDPLY & 0.678555 & 0.474104 & 1.431237 & 0.15460 \\
\hline LNPNPL & -0.871512 & 0.513867 & -1.695987 & $0.09210^{*}$ \\
\hline LNTA & -2.349054 & 0.693411 & -3.387677 & $0.00090^{* * *}$ \\
\hline MCGDP & 0.762976 & 1.13185 & 0.674096 & 0.50140 \\
\hline GRA & 0.044181 & 0.038129 & 1.158729 & 0.24850 \\
\hline PETTAR & -0.333777 & 0.271705 & -1.228453 & 0.22130 \\
\hline ROA & 20.60977 & 2.259407 & 9.121759 & $0.00000^{* * *}$ \\
\hline SHBII & -0.009815 & 0.022574 & -0.434813 & 0.66440 \\
\hline
\end{tabular}

Sukkur IBA Journal of Management and Business - SIJMB | Vol 7 No. 2 July - December 2020 @ Sukkur IBA University 
Note: R-squared $=0.45355 ;$ Adjusted R-Squared $=0.422 ;$ F-statistics $=14.629$ and prob (F-statistics $=0.000000)$; Durbin-Watson Stat $=1.52$

The starred coefficient estimates are significant at $1 \%(* * *), 5 \%(* *)$ and $10 \%(*)$ level.

The significant Regressors of model explain approximately 45 percent of variation in dividend payout ratio. To test the Multicollinearity and autocorrelation issues in given model, the study uses correlation matrix results / variation inflation factor (VIF) and Durbin-Watson statistic respectively. Correlation matrix is already given above and explanation stands same as stated. However, the correlation coefficient value above 0.9 (90 percent) indicates the presence of Multicollinearity issue. The dividend determinant model for Chinese commercial banks shows highest correlation coefficient (0.716 or 71.6 percent) between LNPNPL and LNDPLY. This indicates that the given model is free of Multicollinearity issue. In order to provide another evidence, the study uses value of VIF for presence of Multicollinearity.

Table 4: Multicollinearity Test using VIF

\begin{tabular}{|l|c|c|}
\hline \multirow{2}{*}{\multicolumn{1}{|c|}{ Variables in Model }} & \multicolumn{2}{c|}{ Collinearity Statistics } \\
\cline { 2 - 3 } & Tolerance & VIF \\
\hline total assets & .797 & 1.255 \\
\hline Return on Assets & .470 & 2.127 \\
\hline Growth in Assets & .665 & 1.504 \\
\hline $\begin{array}{l}\text { Provisioning against non- } \\
\text { performing loans }\end{array}$ & .386 & 2.591 \\
\hline Dividend paid last year & .310 & 3.229 \\
\hline $\begin{array}{l}\text { Percent share of institutional } \\
\text { investors }\end{array}$ & .662 & 1.510 \\
\hline Equity to total assets ratio & .555 & 1.800 \\
\hline $\begin{array}{l}\text { Market capitalization of listed } \\
\text { companies (\% of GDP) }\end{array}$ & .733 & 1.365 \\
\hline
\end{tabular}

Hair (2014) suggested that the given model may suffer from Multicollinearity issues if two conditions are met, first VIF value above five (5) and tolerance level below 0.2. For safe side, in this study we consider the VIF value above five (VIF > 5) as an indication of Multicollinearity. The figure above shows that all VIF values for model variables are below 3.22. Therefore, the given model is free of Multicollinearity issue.

\section{Conclusion}

The present model addresses the criticisms in models presented by Lintner (1956); Fama and French (2001) and Dickens at el., (2002) and provides a better model empirical analysis. In addition, includes new variables that are quite significant for banking sector. The selected number of banks in final sample cover more than 90 percent of banking industry in terms of operations, network, assets and profitability. The model for Chinese commercial banks indicates that provisioning against nonperforming loans (LNPNPL), total assets (LNTA) and return on assets (ROA) play significant role in defining variations in dividend payout ratio. LNPL, LNTA and ROA represent (are used as proxies) risk level, size and profitability of bank. LNPNPL significantly and negatively causes dividend policy, this indicates that banks with higher level of risk pay less dividends. Similarly, ROA significantly and positively explains variations in dividend payout ratio. The positive relationship tells that banks

Sukkur IBA Journal of Management and Business - SIJMB | Vol 7 No. 2 July - December 2020 @ Sukkur IBA University 
with higher returns (profitable banks) pay higher dividends. The negative and significant relation (causal) between LNTA and dividend payout indicates that Chines banks pay less dividends as they grow bigger in size. The findings are in line with (Fama and French, 2001; Baker et al., 2006; Mistry, Kohli, H., A. Sharma, et al., (2011); Rodríguez-Pose \& Gill, 2005; Jensen, 1986; and Pruitt \& Gitman, 1991). The findings point out significant but negative impact of size of bank on dividend payout ratio. This means banks start to avoid dividends as they grow older. Furthermore, findings suggest that Chinese banks do not set target dividends hence last year dividend may not be used as a signal of future income.

\section{References:}

Ahmed, HJA \& Shaikh, JM., (2008). Dividend policy choice: do earnings or investment opportunities matter? [J] Afro-Asian Journal of Finance and Accounting, vol. 1 , no. 2, pp. 151-61.

Bishop, Steven R., Harvey R. Crapp, Robert W. Faff, and Garry J. Twite, (2000). [M] Corporate Finance (Prentice Hall Inc., Sydney).

Black, Fischer, (1976). The Dividend Puzzle. [J] Journal of Portfolio Management 2, 5-8.

Fama, EF., and French, KR., (2001). Disappearing dividends: changing firm characteristics or lower propensity to pay? [J] Journal of Applied Corporate Finance, vol. 14, no. 1, pp. 67-79

Huang, JJ., Shen, Y \& Sun, Q., (2011). Nonnegotiable shares, controlling shareholders, and dividend payments in China. [J] Journal of Corporate Finance, vol. 17, no. $1,122-33$.

Lintner, John, 1956, Distribution of Incomes of Corporations Among Dividends, Retained Earnings, and Taxes. [J] American Economic Review 46, 97-113

Miller, M., \& Modigliani, F., (1961). Dividend policy, growth and the valuation of shares. [J] Journal of Business, 34, 411-433.

Mitton, T., (2004). Corporate Governance and Dividend Policy in Emerging Markets. [J] Emerging Markets Review, 409-426

Patra, T., Poshakwale, S \& Ow-Yong, K., (2012). Determinants of corporate dividend policy in Greece. [J] Applied Financial Economics, vol. 22, no. 13, pp. 10791087

Jensen, M. C., (1986). Agency costs of free cash flow, corporate finance, and takeovers. [J] American Economic Review, 76, 323-329.

Gaver, J. J., \& Gaver, K. M., (1993). Additional evidence on the association between the investment opportunity set and corporate financing, dividend, and compensation policies. [J] Journal of Accounting and Economics, 16, 125160.

Grullon, G., Michaery, R., \& Swaminathan, B., (2002). Are dividend changes a sign of firm maturity? [J] Journal of Business, 75, 387-424.

Casey, K. Michael, and Ross N. Dickens, (2000). The Effect of Tax and Regulatory Changes in Commercial Bank Dividend Policy. [J] Quarterly Review of Economics and Finance 40, 279-293.

Lintner, John, (1962). Dividends, Earnings, Leverage, Stock Prices and Supply of Capital to Corporations. [J] The Review of Economics and Statistics 64, 243269.

Watts, R., (1973). The information content of dividends. [J] Journal of Business, 46, 191-211 
Nissim, D., \& Ziv, A., (2001). Dividend changes and future profitability. [J] Journal of Finance, 56, 2111-2133

Hafeez A., and Attiya J., (2009). Dynamics and Determinants of Dividend Policy in Pakistan (Evidence from Karachi Stock Exchange Non-Financial Listed Firms). [J] International Research Journal of Finance and Economics Issue, 25: 148-171.

Okpara, \& Chigozie, G., (2010). A Diagnosis of the Determinant of Dividend Pay-Out Policy in Nigeria: A Factor Analytical Approach. [J] American Journal of Scientific Research (8), 57-67.

Rehman, A., (2012). Determinants of Dividend Payout Ratio: Evidence from Karachi Stock Exchange (KSE). [J] Journal of Contemporary Issues in Business Research, 1(1): 20-27.

Lintner, J., (1965). The valuation of risk assets and the selection of risky investments in stock portfolios and capital budgets. [J] The Review of Economics and Statistics, 47(1): 13-37.

Pandey, I. and R. Bhat, (2007). Dividend behaviour of Indian companies under monetary policy restrictions. [J] Managerial Finance, 33(1): 14-25.

Sheikh, N.A. and Z. Wang, (2011). Determinants of capital structure: An empirical study of firms in manufacturing industry of Pakistan. [J] Managerial Finance, 37(2): 117-133.

Arnott, R.D. and C.S. Asness, (2003). Surprise! Higher dividends= higher earnings growth. [J] Financial Analysts Journal, 70-87.

Amidu, M., \& Abor, J., (2006). Determinants of dividend payout ratios in Ghana. [J] The Journal of Risk Finance, 7(2), $136-145$.

Kangarlouei, S. J., Motavassel, M., azizi, A., \& Farahani, M. S., (2012). The investigation of the relationship between dividend policies, cash-flow uncertainty, contributed capital mix and investment opportunities the case of emerging markets (Tehran Stock Exchange). [J] International Journal of Business and Social Science, 3(2).

Shin, M.-S., Kwon, J.-S., \& Kim, S.-E., (2010). Earned surplus and dividend policy: A test of the financial life cycle theory in Korean capital market. International Research. [J] Journal of Finance and Economics, (59), 86-100.

D’Souza, J., (1999). Agency Cost, Market Risk, Investment Opportunities and Dividend Policy - An International Perspective. [J] Managerial Finance, 25(6): 35-43.

Al-Malkawi, H.A.N., (2007). Determinants of Corporate Dividend Policy in Jordan: An Application of the Tobit Model. [J] Journal of Economic \& Administrative Sciences, 23(2): 44-70.

Adedeji, A., (1998). Does The Pecking Order Hypothesis Explain The Dividend Payout Ratios Of Firms In The UK? [J] Journal of Business Finance and Accounting, 25(9/10): 1127-1155.

Barclay, Michael J., Clifford W. Smith and Ross L. Watts, (1995). The Determinants of Corporate Leverage and Dividend Policies. [J] Journal of Applied Corporate Finance, 7: 4-19.

Pruitt, S.W. and L.J. Gitman, (1991). The Interactions Between the Investment, Financing and Dividend Decisions of Major US Firms. [J] Financial Review, 26(3): 409- 430.

Naeem, S., \& Nasr, M., (2007). Dividend Policy Of Pakistani Firms: Trends and Determinants. [J] International Review of Business Research Papers, III (3), 242-254.

Sukkur IBA Journal of Management and Business - SIJMB | Vol 7 No. 2 July - December 2020 @ Sukkur IBA University 
Truong, T., \& Heaney, R., (2007). Largest shareholder and dividend policy around the world. The Quarterly Review of Economics and Finance, 47, 667-687

Rodríguez-Pose, A. and N. Gill, (2005). On the 'economic dividend' of devolution. [J] Regional Studies, 39(4): 405-420.

Matthias, A. Nnadi and Meg Akpomi, (2008). The Effect of Taxes on Dividend Policy of Banks in Nigeria. [J] International Research Journal of Finance and Economics Issue, 19: 48-55.

Baker, H. K., Mukherjee, T. K., \& Paskelian, O. G., (2006). How Norwegian managers view dividend policy. [J] Global Finance Journal, 17, 155-176.

Mark, E. Holder, Frederick W. Langrehr and J. Lawrence Hexter, (1998). Dividend Policy Determinants: An Investigation of the Influences of Stakeholder Theory. [J] Financial Management, 27(3): 73-82.

Afza, T., \& Mirza, H. H., (2010). Ownership structure and cash flows as determinants of corporate dividend Policy in Pakistan. [J] International Business Research, 3(3), 210-221.

Alli, K.L., A.Q. Khan, et al., (1993). Determinants of corporate dividend policy: a factorial analysis. [J] Financial Review, 28(4): 523-547.

Eriotis, N., (2005). The Effect of Distributed Earnings and Size of the Firm to Its Dividend Policy: Some Greek Data. [J] International Business and Economics Journal, 4(1): 67-74.

Ramli,N.M., 2010. Ownership Structure and Dividend Policy: Evidence from Malaysian Companies. [J] International Review of Business Research Papers, 6(1): 170-180.

Syed Zulfiqar Ali shah, Hui Yuan and Nousheen Zafar, (2010). Earnings Management and Dividend Policy An Empirical comparison between Pakistani Listed Companies and Chinese listed Companies. [J] International Research Journal of Finance and Economics Issue, 35: 51-60.

Abdelsalam, O. and A. El-Masry, (2008). The impact of board independence and ownership structure on the timeliness of corporate internet reporting of Irishlisted companies. [J] Managerial Finance, 34(12): 907-918

Kohli, H., A. Sharma, et al., (2011). Asia 2050: realizing the Asian century. Emerging Markets Forum

Hair, J. Hult, G, Ringle, C. \& Sarstedt, M. (2014) A Primer on Partial Least Squares Structural Equation Modeling (Pls-Sem), [M] SAGE Publications, Inc., United States of America.

Dickens, R.N., Casey, K.M., Newman, J.A., (2002). Bank dividend policy: explanatory factors. [J] Q. Journal of Business and Economics, 41, 3-12. 